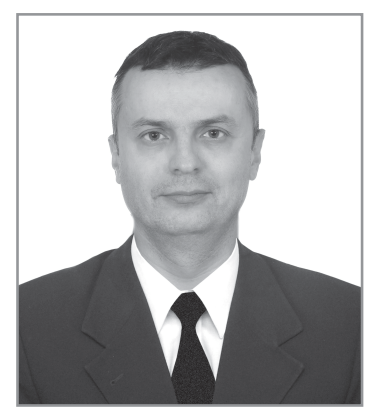

\author{
Vitali Serafimov* \\ $\mathrm{PhD}$ in Law, Docent, Attorney at Law, \\ Beijing Allied Law Offices \\ (Beijing, China) \\ https://orcid.org/0000-0002-0436-2071
}

*Vitali Serafimov, PhD in Law, Docent, Attorney at Law, Beijing Allied Law Offices (Xintiandi B Xibahenanlu jia 1, District Chaoyang, Beijing, China).

UDC 342.951: $35.078 .3(477)$

DOI 10.26886/2524-101X.1.2020.2

\title{
SUPERVISION (CONTROL) IN THE SPHERE OF MARINE ENVIRONMENT PROTECTION IN UKRAINE: NEW INSTITUTIONAL TRANSFORMATIONS
}

\section{НАГЛЯД (КОНТРОЛЬ) У СФЕРІ ОХОРОНИ МОРСЬКОГО ДОВКІЛЛЯ В УКРАЇНІ: НОВІТНІ ІНСТИТУЦЙНІ ПЕРЕТВОРЕННЯ}

\section{ABSTRACT}

This article describes the reforms that currently occur to improve the legal support for the public (state) administration of marine environment protection in Ukraine in the direction of control and supervision activities in the marine environment of Ukraine. In particular, the author analyzes the latest changes in the institutional support of control and supervisory functions in the field of marine environment protection. In the article it is considered the compelled move of the Government of Ukraine to eliminate two marine environmental inspectorates, which has become the next stage in the reform of the state administration in the state's environmental sector. This step is a temporary redistribution of the functions of territorial bodies of the State Environmental Inspectorate of Ukraine on the way of building an updated system of efficient public administration, ensuring the reliable fulfillment of the ecological function of the modern Ukrainian state through the implementation 
of control and supervision procedures in the seaports. It is noted that this will facilitate the gradual formation, in accordance with the Concept of reforming the system of state supervision (control) in the field of environmental protection 2017 of an integrated system of public (state) administration, which could ensure the implementation of reforms in the field of environmental activities, in particular with regard to improving the control and supervision procedures. Initiatives to adopt a special Law of Ukraine "On State Environmental Control" were also supported.

The key words: control, supervision, environmental protection, marine environmental inspectorates, reform.

\section{Introduction}

At the beginning of 2020, the Cabinet of Ministers of Ukraine adopted the decision (resolution of 29.01.2020, № 39) on the liquidation of the Azov Marine Environmental Inspectorate and the State Environmental Inspectorate of the Crimean Black Sea District. This compelled step came out from the "sad" results of the activities of the aforementioned inspectorates and a new stage of reforming the public (state) administration of the environmental sphere (its control and supervisory component). For several years, the state institutional mechanism of the environmental sector has been gradually updated in Ukraine. The active search for the new effective models of integrated management and provision of efficient environmental control are not always consistent. Nevertheless, the presence of these efforts and the steps already taken towards upgrading the system indicate the urgent need and the agenda for truly effective and much needed reforms. However, the results of the current inspectorates indicate that the necessary changes are neglected even during the period of active reform and efforts of the state leadership to simplify and reduce the environmental control in the country to the level of international standards.

\section{Methodology}

Taking into consideration the significant institutional changes currently underway in the public (state) administration system in Ukraine, as well as the significant "greening" of all state-making, law-making and enforcement mechanisms, the issue of reforming the state bodies entrusted with state supervision (control) functions in the field of environmental protection and rational use, reproduction and protection of natural resources, gain of particular, high relevance. The transformations that have been characteristic of the system of state control bodies in the field of environmental protection since 2017, have not been yet the subject of 
a separate scientific administrative and legal research, and the recent steps towards the establishment of an effective system of environmental control require scientific legal handling and elaboration of the suggestions for its rapid and effective improvement. The theoretical basis of this research were the works of V.M. Garashchuk, O.V. Golovkin, A.L. Pravdyuk. On the basis of them, by means of general scientific dialectical and historical methods, methods of formal legal analysis, synthesis, comparison and scientific forecasting, the reforms that are taking place in the field of state administration of environmental protection are characterized. The directions of improvement of legal support of the system of public (state) administration of marine environment protection in Ukraine in the direction of control and supervisory activity in the field of the marine environment protection in Ukraine are determined.

\section{Modern institutional mechanism of supervision (control) in the field of marine environment protection in Ukraine}

According to Art. 16 of the Law of Ukraine of 25.06.1991 "On Environmental Protection", the administration of environmental protection consists in the implementation in this area, in particular, the functions of observation, research, strategic environmental assessment, environmental impact assessment, control. State administration in the field of environmental protection is carried out by the Cabinet of Ministers of Ukraine, local councils and executive bodies of rural, settlement, city councils, state bodies of environmental protection and use of natural resources and other state bodies in accordance with the legislation of Ukraine. The state bodies of administration in the field of environmental protection and use of natural resources are the central body of executive power, which provides the formation of state policy in the field of environmental protection, the central body of executive power, which implements the state policy in the field of environmental protection, regional and equitable these state administrations, other state bodies, whose competence to exercise these functions is assigned by the laws of Ukraine.

According to the Regulation on the Ministry of Energy and Environmental Protection of Ukraine, approved by the Cabinet of Ministers of Ukraine of January 21, 2015, № 32 (as amended by the Cabinet of Ministers of Ukraine on September 18, 2019, № 847), the Ministry of Energy is the main body in the system of central executive bodies which ensures, in particular, the formation and implementation of 
state policies in the field of environmental protection and environmental security; in the field of fisheries and fishing industry, protection, use and reproduction of aquatic biological resources, regulation of fisheries and safety of navigation of vessels of the fisheries' fleet; the formation of the state policy on the implementation of state supervision (control) in the field of environmental protection, rational use, reproduction and protection of natural resources.

The implementation of the state policy on the conducting of state supervision (control) in the field of environmental protection, rational use, reproduction and protection of natural resources, in accordance with the Regulation approved by the Cabinet of Ministers of Ukraine № 275 of April 19, 2017, is entrusted to the State Environmental Inspectorate of Ukraine (State Environmental Inspectorate), that is the central executive body, which activities are directed and coordinated by the Cabinet of Ministers of Ukraine through the Minister of Energy and Environment. Also, the powers of the State Environmental Inspectorate are enshrined in Art. 202 of the Law of Ukraine of 25.06.1991 "On Environmental Protection".

In accordance with the Rules for the Protection of Inland Sea Waters and the Territorial Sea of Ukraine from Pollution and Contamination, approved by the Resolution of the Cabinet of Ministers of Ukraine of February 29, 1996 № 269 (as amended by the Cabinet of Ministers of Ukraine of March 29, 2002, № 431), territorial and inter-regional territorial bodies of the State Inspectorate carry out inspections in places of drain of bilge, sewage and ballast water (except isolated ballast), the disposal of which is carried out from ships to inland sea waters and territorial sea, for compliance with the regulations only in the event of the detection of visible traces of oil or oil-containing or other contaminants in the area of the probable disposal, which has led to the actual deterioration of the water quality (paragraph $5^{1}$ ). In the previous version of the Rules, such powers were entrusted to the marine environmental inspectorates of the State Environmental Inspectorate, and in accordance with the aforementioned Cabinet of Ministers of Ukraine Decree № 39 of 29.01.2020, replaced by the territorial and interregional territorial bodies of the State Environmental Inspectorate.

The powers of the State Environmental Inspectorate were also noted in the Resolution of the Cabinet of Ministers of Ukraine of March 20, 1995 № 1988 “On Exercising Environmental Control at Points of Crossing the State Border”. Thus, the State Environmental Inspectorate should ensure 
that in particular, the environmental control is carried out over the air and ground vehicles (except passenger cars) at points of entry across the state border (except for environmental control by customs officials in the form of prior documentary control), in accordance with the list, determined by the Cabinet of Ministers of Ukraine. Environmental control of water vehicles is carried out when visible floating particles are discharged from the vessel or visible traces of oil, oil-containing or other contaminants appear in the discharge area, which resulted in actual deterioration of water quality in accordance with the background water quality indicators in the water use area.

Indeed, the priority areas of control in Ukraine include the control over maintaining environmental security or environmental control (Garashchuk, 2002, pp. 133-134). At the same time, it is particularly important to adhere to the concept of such control that would meet world-wide standards. And if control functions carried out domestically may have certain (or even significant) national characteristics, then in the field of control formalities in maritime transport (in seaports), they must be harmonized with global (or at least regional) requirements. This makes frequent mention in the environmental policy documents of European standards and good practices in the field of the environmental control.

\section{Environmental policy documents:}

\section{impact on the reform of the supervision (control) system}

in the field of the environmental protection

The choice of the European vector of our state development, the diversity of the forms of ownership in the conditions of functioning of the market economy leads to the formation of particular specifics of the country's legislation on state environmental control, which, on the one hand, determines the minimum necessary level of state intervention in the process of day-to-day management of enterprise activity, on the otherrequires maximum compliance with community-wide environmental rules (Pravdyuk, 2016, p. 87). The current program documents of the environmental sector of Ukraine determine the next steps to reform the state administration of this field [and its component - control and supervisory activity].

Thus, the Concept of Reforming the System of State Supervision(Control) in the Field of Environmental Protection, approved by the decree of the Cabinet of Ministers of Ukraine of May 31, 2017 № 616-p, (hereinafter - 
the Concept) provides for reforming the system of management of the field of environmental monitoring and supervision (control) with a view to create an integrated system capable of implementing reforms in the field of environmental protection, since supervisory (control) functions are being duplicated by central executive authorities, there is no single approach to performing functions. The powers to supervise (control) are exercised by the State Environmental Inspectorate, the State Service for Geology and Subsoil, the State Forestry Agency, the State Service of Ukraine for Geodesy, Cartography and Cadastre, the State Fisheries Agency, the State Consumer Service, and the State Service for Transport Safety. The State Environmental Inspectorate and its territorial bodies will also be liquidated (sections "Problem that needs to be solved" and "Purpose and terms of implementation of the Concept").

In the General Provisions of the Concept it was also specifically mentioned about the establishment of the State Environmental Protection Service and the liquidation of the State Environmental Inspectorate, which is the fulfillment of the obligations provided for the Association Agreement between Ukraine, on the one hand, and the European Union, the European Atomic Energy Community and their Member States, on the other hand, and the Plan of legislative support of reforms in Ukraine, approved by the resolution of the Verkhovna Rada of Ukraine of June 4, 2015 № 509-VIII, with the aim of improving the state system of environmental monitoring and simplifying the system of state supervision (control) in the field of environmental protection, rational use, reproduction and protection of natural resources.

In the Fundamental Principles (Strategy) of the State Environmental Policy of Ukraine for the period up to 2030, approved by the Law of Ukraine of February 28, 2019 № 2697-VIII, it is also noted the inefficient system of public administration in the field of environmental protection and regulation of the use of natural resources (Section I. Existing problems and current state of the environment in Ukraine) and among the expected results of the implementation of this strategy it is denoted that the institutional capacity of the central executive body which ensures the formation and implementation of the state policy in the field of environmental protection and ecological safety will be strengthened by reforming and improving the state administration and the approach of the environmental legislation to the ecological law of the European Union (Section VI. Expected results). 
In order to fulfil the tasks and objectives of these program documents, pursuant to the Resolution of the Cabinet of Ministers of Ukraine № 750 "Some Issues of the State Environmental Protection Service of Ukraine" (hereinafter - Resolution № 750), the State Environmental Inspectorate, its territorial and interregional bodies were liquidated and it was created the State Environmental Protection Service of Ukraine as the central executive authority (the decree came into force on August 24, 2019). Two months later, Resolution № 750 became invalid on the basis of the Cabinet of Ministers of Ukraine Resolution № 873 of October 12, 2019 (came into force on October 19, 2019) and the activity of the State Environmental Inspectorate and its territorial and interregional bodies was restored. This happened, first of all, due to the poor elaboration of the legislation necessary for the functioning of the new nature protection body - the State Environmental Protection Service of Ukraine.

According to the Regulations on the State Azov Marine Environmental Inspectorate, approved by the Order of the State Environmental Inspectorate of Ukraine dated September 28, 2017 № 652, the State Azov Marine Environmental Inspectorate (hereinafter referred to as the Azov Inspectorate) is a territorial body of the State Environmental Inspectorate of Ukraine and is subordinate to it (p. 1), and the State Environmental Inspectorate of the Crimean and Black Sea District (hereinafter - the Crimean Black Sea District Inspectorate), in accordance with the Regulation approved by the order of the State Environmental Inspectorate of Ukraine dated November 27, 2018 № 256 is the interregional territorial body of the State Environmental Inspectorate of Ukraine and is subordinate to it (p. 1). And it is precisely with regard to the activity of these two inspectorates there are the biggest number of claims even after the liquidation of the environmental control in the Ukrainian seaports.

The purpose of the two inspectorates was to strengthen the environmental controls at ports. But instead of proper control, numerous complaints from international maritime carriers began to arrive and scandals began to arise because of the unjustified delays of vessels by environmental inspectors, which led to the demand for bribes. In addition, according to the information of the Administration of the Sea Ports of Ukraine, the inspectorate does not respond to their calls for fixing the cases of pollution of the water area. Because of sabotaging the activities, the disciplinary proceedings have been initiated against the heads of the inspectorates. During the entire existence of the inspectorate, they did not justify the tasks assigned, and the 
state suffered only wastes and image losses (Uriad likviduvav dvi morski ekolohichni inspektsii).

\section{Defects of the modern organizational and legal mechanism of supervision (control) in the field of protection of marine environment of Ukraine}

Environmental control at the Ukrainian seaports has been perhaps the most discussed issue in the specialized periodicals and at the coordination activities of the bodies involved in port control procedures since 2015. It was in 2015 that the mandatory control of isolated ballast was abolished in Ukraine. Environmentalists were barred from boarding the vessel and taking samples independently. However, in making this decision, Ukrainian legislators have not abolished the state standard for ballast water indicators.

In September 2018, the Verkhovna Rada of Ukraine adopted the Law "On Amendments to the Customs Code of Ukraine and Some Other Laws of Ukraine on the Introduction of the Single Window Mechanism and Optimization of Control Procedures for the Movement of Goods across the Customs Border of Ukraine", however, the issue of ballast water control was again remained unresolved.

In October 2018, the representatives of the State Environmental Inspectorate of the Crimean Black Sea District repeatedly tried to make improper sampling of isolated ballast on Navios Coral vessel (Panama flag) at the Nikolaev seaport and the Black Sea seaport, causing the shipowner to suffer damage due to the vessel being idle. At the end of 2019, in case № 420/4422/19, the Odessa District Administrative Court upheld the suit of Castalia Shipholding S.A. to the State Environmental Inspectorate of the Crimean Black Sea District on the recognition of illegal and the cancellation of decisions from 18.02.2019 № 11 and from 20.02.2019 № 12, the recognition as illegal and the cancellation of the claim from 20.02.2019 № 100006, recovery of funds, and declared unlawful and cancelled the decision of the State Environmental Inspectorate of Crimea-Black Sea District № 11 of 18.02 .2019 to ban the exit of the vessel "CAPTAIN ADAMS" (IMO 9737618, flag of Liberia) from the "Chornomorsk" port. And these cases are not isolated.

In addition, the results of the operation of these two marine environmental inspectorates indicate that their work is inefficient (compared to other territorial bodies of the State Environmental Inspectorate). This is followed by a study of the results for the three quarters of 2019 posted on the 
official website (Rezultaty zdiisnennia derzhavnoho nahliadu (kontroliu) u sferi okhorony navkolyshnoho pryrodnoho seredovyshcha za 9 misiatsiv 2019 roku). Moreover, there were repeated and unlawful inspections and detentions of the ships in the seaports, which were carried out in spite of the requirements of the Cabinet of Ministers of Ukraine of March 27, 2019 № 367 "Some issues of deregulation of economic activity” and the moratorium of the President of Ukraine on environmental inspections in the ports (Prymusova vidstavka hlavy DFS, «naizd» Zelenskoho na "ArcelorMittal Kryvyi Rih» ta masovi zvilnennia v Huawei). Thus, in 2019, despite the changes in the legislation, the lack of powers of environmental inspectors to inspect vessels, independently to board, illegal detentions of the vessels in the seaports of Ukraine continued: in the port of "Chornomorsk" during the Christmas holidays the inspectors of the State Environmental Inspectorate tried to detain three vessels allegedly for environmental pollution (Kabmin skasuvav kontrol izolovanykh balastnykh vod u portakh). This was the reason for the elimination of these inspections and the transfer of control functions of vessels to the relevant territorial bodies of the State Environmental Inspectorate, when every detention of the vessel should be authorized exclusively by the head of the State Environmental Inspectorate of Ukraine (Uriad ukhvalyv rishennia, yakym likvidovuie "morski inspektsii" cherez yikhniu neefektyvnist).

\section{Conclusions}

Thus, the considered compelled step to liquidate two marine environmental inspectorates became an another stage of reforming the state administration of the state's environmental protection sphere. It is a temporary redistribution of the functions of territorial bodies of the State Environmental Inspectorate of Ukraine on the way of building an updated system of efficient public administration, ensuring the reliable fulfillment of the ecological function of the modern Ukrainian state through the implementation of control and supervisory procedures in the seaports. It will also facilitate the gradual creation, in accordance with the Concept of 2017, of an integrated system of public (state) administration capable of implementing the reforms in the field of the environmental protection, in particular with regard to improving control and supervisory procedures. The adoption of a special Law "On State Environmental Control", which was introduced at the end of last year and may be the first modern attempt to legislate the basic principles of exercising state control over 
the observance of the whole spectrum of environmental legislation by the bodies of authorities, entities and individuals. The bill combines the control functions of all currently operating state bodies in the field of environmental protection and its components into one body of state environmental control, operating at the central and regional levels (Hromadskist prezentuie proekt zakonu pro derzhavnyi ekolohichnyi kontrol).

\section{REFERENCES}

Harashchuk, V.M. (2002). Ekolohichnyi kontrol yak chynnyk ekolohichnoi bezpeky suspilstva [Environmental control as a factor of environmental safety of society]. Derzhavne budivnytstvo ta mistseve samovriaduvannia. [State Building and Local Government], no. 3, 133-140. [in Ukrainian].

Hromadskist prezentuie proekt zakonu pro derzhavnyi ekolohichnyi kontrol [The society presents the draft law on state environmental control]. Hurt. [Group]. https://gurt.org.ua/ news/informator/55399/ (2020, January, 15) [in Ukrainian].

Kabmin skasuvav kontrol izolovanykh balastnykh vod u portakh [Cabinet of Ministers abolished control of isolated ballast water in ports]. Porty Ukrainy. [Ports of Ukraine]. Retrieved from: https://ports.com.ua/uk/news/kabmin-otmenil-kontrol-izolirovannykhballastnykh-vod-v-portakh (2020, February, 25) [in Ukrainian].

Nakaz pro zatverdzhennia Polozhennia pro Derzhavnu Azovsku morsku ekolohichnu inspektsiiu, 2017 (Derzhavna ekolohichna inspektsiia Ukrainy) [Order on approval of the Regulation on the State Azov Marine Environmental Inspection, 2017 (State Environmental Inspectorate of Ukraine)]. Ofitsiinyi sait Derzhavnoi Azovskoi morskoi ekolohichnoi inspektsii. [Official site of the State Azov Marine Environmental Inspectorate]. Retrieved from: https://azov.dei.gov.ua/posts/8 (2020, February, 25) [in Ukrainian].

Nakaz pro zatverdzhennia Polozhennia pro Derzhavnu ekolohichnu inspektsiiu KrymskoChornomorskoho okruhu, 2018 (Derzhavna ekolohichna inspektsiia Ukrainy) [Order on approval of the Regulation on the State Environmental Inspection of the Crimean Black Sea District, 2018 (State Environmental Inspectorate of Ukraine)]. Ofitsiinyi sait Derzhavnoi ekolohichnoi inspektsii Ukrainy. [Official web-site of the State Environmental Inspectorate of Ukraine]. Retrieved from: https://www.dei.gov.ua/posts/273 (2020, February, 25) [in Ukrainian].

Postanova pro deiaki pytannia derehuliatsii hospodarskoi diialnosti, 2019 (Kabinet Ministriv Ukrainy) [Resolution on some issues of deregulation of economic activity, 2019 (Cabinet of Ministers of Ukraine)]. Ofitsiinyi visnyk Ukrainy. [Official Bulletin of Ukraine], 36, 1260. [in Ukrainian].

Postanova pro deiaki pytannia Derzhavnoi pryrodookhoronnoi sluzhby Ukrainy, 2019 (Kabinet Ministriv Ukrainy) [Resolution on some issues of the state environmental protection service of Ukraine, 2019 (Cabinet of Ministers of Ukraine)]. Ofitsiinyi visnyk Ukrainy. [Official Bulletin of Ukraine], 68, 2360. [in Ukrainian]. 
Postanova pro likvidatsiiu terytorialnoho ta mizhrehionalnoho terytorialnoho orhanu Derzhavnoi ekolohichnoi inspektsii, 2020 (Kabinet Ministriv Ukrainy) [Resolution on liquidation of the territorial and interregional territorial authority of the State Environmental Inspectorate, 2020 (Cabinet of Ministers of Ukraine)]. Uriadovyi kurier. [Government courier]. 05.02.2020. № 22. [in Ukrainian].

Postanova pro Plan zakonodavchoho zabezpechennia reform v Ukraini, 2015 (Kabinet Ministriv Ukrainy) [Resolution on the Legislative Support Plan for Reforms in Ukraine, 2015 (Cabinet of Ministers of Ukraine)]. Ofitsiinyi visnyk Ukrainy. [Official Bulletin of Ukraine], 52, 1668. [in Ukrainian].

Postanova pro vnesennia zmin do deiakykh postanov Kabinetu Ministriv Ukrainy, 2019 (Kabinet Ministriv Ukrainy) [Resolution on Amendments to Some Resolutions of the Cabinet of Ministers of Ukraine, 2019 (Cabinet of Ministers of Ukraine)]. Ofitsiinyi visnyk Ukrainy. [Official Bulletin of Ukraine], 78, 2694. [in Ukrainian].

Postanova pro vnesennia zmin do Pravyl okhorony vnutrishnikh morskykh vod $i$ terytorialnoho moria Ukrainy vid zabrudnennia ta zasmichennia, 2015 (Kabinet Ministriv Ukrainy) [Resolution on Amendments to the Rules for the Protection of Inland Sea Waters and the Territorial Sea of Ukraine from Pollution and Contamination, 2015 (Cabinet of Ministers of Ukraine)]. Ofitsiinyi visnyk Ukrainy. [Official Bulletin of Ukraine]. 2015. № 59. St. 1937. [in Ukrainian].

Postanova pro vyznannia takoiu, shcho vtratyla chynnist, postanovy Kabinetu Ministriv Ukrainy vid 14 serpnia 2019 r. № 750, 2019 (Kabinet Ministriv Ukrainy) [Resolution on Recognition of the Decommitment of the Cabinet of Ministers of Ukraine of August 14, 2019 No. 750, 2019 (Cabinet of Ministers of Ukraine)]. Ofitsiinyi visnyk Ukrainy. [Official Bulletin of Ukraine], 84, 2858. [in Ukrainian].

Postanova pro zatverdzhennia Polozhennia pro Derzhavnu ekolohichnu inspektsiiu Ukrainy, 2017 (Kabinet Ministriv Ukrainy) [Resolution on approving the Regulation on the State Environmental Inspectorate of Ukraine, 2017 (Cabinet of Ministers of Ukraine)]. Ofitsiinyi visnyk Ukrainy. [Official Bulletin of Ukraine], 36, 1131. [in Ukrainian].

Postanova pro zdiisnennia ekolohichnoho kontroliu v punktakh propusku cherez derzhavnyi kordon, 1995 (Kabinet Ministriv Ukrainy) [Resolution on the implementation of environmental control at border crossing points, 1995 (Cabinet of Ministers of Ukraine)]. Ofitsiinyi veb-sait Verkhovnoi Rady Ukrainy. [The official website of the Verkhovna Rada of Ukraine]. Retrieved from: https://zakon.rada.gov.ua/laws/show/198-95-p (2020, January, 25) [in Ukrainian].

Postanova pro zatverdzhennia Pravyl okhorony vnutrishnikh morskykh vod i terytorialnoho moria vid zabrudnennia ta zasmichennia, 2002 (Kabinet Ministriv Ukrainy) [Resolution approving the Rules for the Protection of Inland Sea Waters and Territorial Sea from Pollution and Contamination, 2002 (Cabinet of Ministers of Ukraine)]. Ofitsiinyi visnyk Ukrainy. [Official Bulletin of Ukraine], 14, 741. [in Ukrainian]. 
Pravdiuk, A.L. (2016). Mekhanizm pravovoho rehuliuvannia derzhavnoho ekolohichnoho kontroliu [The mechanism of legal regulation of state environmental control]. Pravo $i$ suspilstvo. [Law and Society], no. 2, 2, 87-92. [in Ukrainian].

Prymusova vidstavka hlavy DFS, "naizd" Zelenskoho na "ArcelorMittal Kryvyi Rih" ta masovi zvilnennia v Huawei [Forced resignation of DFS head, Zelensky's "assault" on "ArcelorMittal Krivoy Rog" and mass dismissals in Huawei]. Biznes. [Business]. Retrieved from: https://business.ua/news/5861-za-vikhidni-primusova-vidstavka-glavi-dfs-najizdzelenskogo-na-arcelormittal-krivij-rig-ta-masovi-zvilnennya-v-huawei (2020, January, 25) [in Ukrainian].

Rezultaty zdiisnennia derzhavnoho nahliadu (kontroliu) u sferi okhorony navkolyshnoho pryrodnoho seredovyshcha za 9 misiatsiv 2019 roku [The results of the state control in the field of environmental protection for the 9 months of 2019]. Yedynyi derzhavnyi vebportal vidkrytykh danykh. [The single state open source web portal]. Retrieved from: https://data.gov.ua/dataset/7faa4182-63fb-4e1b-8482-d4358b6be208/resource/8155276203c1-439a-8a24-4dc24318ad72 (2020, January, 25) [in Ukrainian].

Rishennia u spravi № 420/4422/19 (Odeskyi okruzhnyi administratyvnyi sud) [Judgment in Case No. 420/4422/19 (Odessa District Administrative Court)]. YouControl. Retrieved from: https://youcontrol.com.ua/ru/catalog/court-document/85222022/ (2020, January, 25) [in Ukrainian].

Rozporiadzhennia pro skhvalennia Kontseptsii reformuvannia systemy derzhavnoho nahliadu (kontroliu) u sferi okhorony navkolyshnoho pryrodnoho seredovyshcha, 2017 (Kabinet Ministriv Ukrainy) [Order on approval of the Concept of reforming the system of state control in the sphere of environmental protection, 2017 (Cabinet of Ministers of Ukraine)]. Ofitsiinyi visnyk Ukrainy. [Official Bulletin of Ukraine], 76, 2336. [in Ukrainian].

Uhoda pro asotsiatsiiu, 2014 (Ukraina, Yevropeiskyi Soiuz) [Association agreement, 2014 (Ukraine, European Union]. Ofitsiinyi visnyk Ukrainy. [Official Bulletin of Ukraine], 75, 1, 2125. [in Ukrainian].

Uriad likviduvav dvi morski ekolohichni inspektsii [The government has eliminated two marine environmental inspectorates]. Ofitsiinyi sait Ministerstva enerhetyky ta zakhystu dovkillia. [The official website of the Ministry of Energy and the Environment]. Retrieved from: https://menr.gov.ua/news/34496.html (2020, February, 5) [in Ukrainian].

Uriad ukhvalyv rishennia, yakym likvidovuie "morski inspektsii" cherez yikhniu neefektyvnist [The government has decided to eliminate "maritime inspections" because of their inefficiency]. Ukrinform. https://www.ukrinform.ua/rubric-society/2865178-vukrainskih-portah-likvidovuut-morski-inspekcii.html (2020, February, 5) [in Ukrainian].

Zakon pro okhoronu navkolyshnoho pryrodnoho seredovyshcha, 1991 (Verkhovna Rada Ukrainy) [Law on Environmental Protection, 1991 (Verkhovna Rada of Ukraine)]. Vidomosti Verkhovnoi Rady Ukrainy. [Statements of the Verkhovna Rada of Ukraine], 41, 546. [in Ukrainian]. 
Zakon pro Osnovni zasady (stratehiiu) derzhavnoi ekolohichnoi polityky Ukrainy na period do 2030 roku, 2019 (Verkhovna Rada Ukrainy) [Law on the Fundamental Principles (Strategy) of the State Environmental Policy of Ukraine until 2030, 2019 (Verkhovna Rada of Ukraine)]. Ofitsiinyi visnyk Ukrainy. [Official Bulletin of Ukraine], 28, 980. [in Ukrainian].

Zakon pro vnesennia zmin do Mytnoho kodeksu Ukrainy ta deiakykh inshykh zakoniv Ukrainy shchodo zaprovadzhennia mekhanizmu "iedynoho vikna" ta optymizatsii zdiisnennia kontrolnykh protsedur pry peremishchenni tovariv cherez mytnyi kordon Ukrainy, 2017 (Verkhovna Rada Ukrainy) [Law on Amendments to the Customs Code of Ukraine and some other laws of Ukraine on the introduction of the single window mechanism and optimization of control procedures for the movement of goods across the customs border of Ukraine, 2017 (Verkhovna Rada of Ukraine)]. Ofitsiinyi visnyk Ukrainy. [Official Bulletin of Ukraine], 2018. № 78. St. 2590. [in Ukrainian].

\section{АНОТАЦІЯ}

Серафімов В.В. Нагляд (контроль) у сфері охорони морського довкілля в Украӥні: новітні інституційні перетворення. - Стаття.

У даній статті охарактеризовано реформи, що відбуваються на теперішній час 3 метою удосконалення правового забезпечення системи публічного (державного) адміністрування охорони морського довкілля в Україні у напрямі контрольно-наглядової діяльності України. Зокрема, автор аналізує новітні зміни у інституційному забезпеченні контрольно-наглядових функцій у сфері охорони навколишнього морського середовища. Розглядає вплив на реформування системи контролю (нагляду) у сфері охорони навколишнього середовища програмних документів природоохоронної сфери: Концепцію реформування системи державного нагляду (контролю) у сфері охорони навколишнього природного середовища 2017 р. та Основні засади (стратегію) державної екологічної політики України на період до 2030 року, затверджені Законом України від 28.02.2019 р. У статті розглянуто вимушений крок Уряду України з ліквідації двох морських екологічних інспекцій, що став черговим етапом реформування державного управління у природоохоронній галузі держави. Він $є$ тимчасовим перерозподілом функцій територіальних органів Державної екологічної інспекції України на шляху побудови оновленої системи ефективного публічного адміністрування, забезпечення надійного виконання екологічної функції сучасної Української держави шляхом здійснення контрольно-наглядових процедур у морських портах. Відзначено, що це сприятиме поступовому формуванню відповідно до Концепції реформування системи державного нагляду (контролю) у сфері охорони навколишнього природного середовища 2017 р. інтегрованої системи публічного (державного) адміністрування, спроможної забезпечити реалізацію реформ у сфері природоохоронної діяльності, зокрема щодо удосконалення контрольно-наглядових процедур. Також підтримано ініціативи щодо прийняття спеціального Закону України “Про державний екологічний контроль".

Ключові слова: контроль, нагляд, охорона довкілля, морські екологічні інспекції, реформування. 


\section{АННОТАЦИЯ}

Серафимов В.В. Надзор (контроль) в сфере охраны морской среды в Украине: новые институциональные преобразования. - Статья.

В данной статье охарактеризованы реформы, происходящие в настоящее время в целях совершенствования правового обеспечения системы публичного (государственного) администрирования охраны морской среды в Украине в направлении контрольно-надзорной деятельности. В частности, автор анализирует новые изменения в институциональном обеспечении контрольно-надзорных функций в сфере охраны окружающей морской среды. Рассматривает влияние на реформирование системы контроля (надзора) в сфере охраны окружающей среды программных документов природоохранной сферы: Концепции реформирования системы государственного надзора (контроля) в сфере охраны окружающей природной среды 2017 года и Основных положений (стратегии) государственной экологической политики Украины на период до 2030 года, утвержденных Законом Украины от 28.02.2019 г. В статье рассмотрен вынужденный шаг Правительства Украины по ликвидации двух морских экологических инспекций, который стал очередным этапом реформирования государственного управления в природоохранной отрасли государства. Он является временным перераспределением функций территориальных органов Государственной экологической инспекции Украины на пути построения обновленной системы эффективного публичного администрирования, обеспечения надежного выполнения экологической функции современного Украинского государства путем осуществления контрольно-надзорных процедур в морских портах. Отмечено, что это будет способствовать постепенному формированию в соответствии с Концепцией реформирования системы государственного надзора (контроля) в сфере охраны окружающей природной среды 2017 г. интегрированной системы публичного (государственного) администрирования, способной обеспечить реализацию реформ в сфере природоохранной деятельности, в частности по совершенствованию контрольно-надзорных процедур. Также поддержаны инициативы по принятию специального Закона Украины “О государственном экологическом контроле".

Ключевые слова: контроль, надзор, охрана окружающей среды, морские экологические инспекции, реформирование. 